\title{
Spectrum of acute kidney injury in obstetrics
}

\section{Amandeep Kaur ${ }^{1 *}$, Seema Chopra ${ }^{1}$, Vanita Suri' ${ }^{1}$, Harbir Singh Kohli ${ }^{2}$}

\author{
${ }^{1}$ Department of Obstetrics and Gynecology, ${ }^{2}$ Department of Nephrology, Post Graduate Institute of Medical Education \\ and Research, Chandigarh, India
}

Received: 22 July 2018

Accepted: 28 August 2018

\section{*Correspondence:}

Dr. Amandeep Kaur,

E-mail: k.amandeep22@yahoo.com

Copyright: (c) the author(s), publisher and licensee Medip Academy. This is an open-access article distributed under the terms of the Creative Commons Attribution Non-Commercial License, which permits unrestricted non-commercial use, distribution, and reproduction in any medium, provided the original work is properly cited.

\begin{abstract}
Background: Acute kidney injury (AKI) associated with pregnancy is a serious medical complication which can lead to significant maternal as well as perinatal morbidity and mortality.

Methods: Forty antenatal/postnatal /postabortal patients who fulfilled the Acute kidney injury network criteria were enrolled and followed up till 3 months of acute insult/ postpartum.

Results: Majority of the patients, 23/40(57.5\%) with AKI presented in postpartum period, 14/40(35\%) developed AKI in antenatal period and 3/40(7.5\%) were postabortal. AKI was attributable mostly to sepsis in $11 / 40(27.5 \%)$ followed by hypertension and its complications which included eclampsia in 5/40(12.5\%) and HELLP syndrome in $3 / 40(7.5 \%) .5 / 40(12.5 \%)$ patients had postpartum haemorrhage and abruptio placentae was found in 2/40(5\%). Renal replacement therapy (RRT) was the treatment in majority of them $28(70 \%)$. 25/40(62.5\%) had complete recovery of their renal functions whereas maternal mortality was seen in 10/40(25\%) patients. Prolonged anuria was found to be highly significant in our study and served as poor prognostic factor towards maternal outcome $(\mathrm{p}=0.034)$. Out of 37 patients, 21(56.7\%) had live births and 16 patients $(43.2 \%)$ had still births.

Conclusions: Timely initiation of RRT in patients with AKI associated with pregnancy has a good maternal outcome in the form of complete recovery of renal functions.
\end{abstract}

Keywords: Acute kidney injury, Renal replacement therapy, Sepsis

\section{INTRODUCTION}

Acute Kidney Injury (AKI) is one of the most challenging problems faced by clinicians in the tropics owing to its fast-changing burden.

Incidence of AKI in obstetric population in developing countries is high with 4.2-15\% compared with developed nations (1-2.8\%). ${ }^{1-2}$ Obstetric AKI has a bimodal occurrence in developing countries with first peak between 8 and 16 weeks of gestation in association with septic abortions while late peak is associated with obstetric complications such as preeclampsia-eclampsia, abruptio placentae, uterine haemorrhage, and puerperal sepsis and microangiopathies..$^{3-5}$ Recovery occurs in $60 \%$ to $90 \%$ of cases. The true epidemiological picture of AKI in the tropics is not well understood due to the late presentation of patients to tertiary centres and due to absence of meta analyses it is difficult to precisely estimate its actual incidence. Due to paucity of data, this study has been conducted to know the spectrum of AKI in terms of causative factors, management/ interventions and follow up.

\section{METHODS}

This Prospective observational study was carried out in the labor ward of Obstetrics and Gynaecology department 
and Dialysis unit of Nephrology department of Post Graduate Institute of Medical Education and Research (PGIMER), Chandigarh from July 2013 to June 2014 after approval by ethics committee and informed consent was obtained from all individual participants included in the study.

Antenatal/postnatal/postabortal patients who presented with oliguria (urine output $<500 \mathrm{ml} / 24$ hours) or anuria (urine output $<50 \mathrm{ml} / 24$ hours) and fulfilled Acute kidney injury network (AKIN) criteria (AKI which occurs in $<48$ hours and deterioration occurs in the renal function in terms of increase in serum creatinine, either absolute i.e $>=0.3 \mathrm{mg} / \mathrm{dl}(>=26.4 \mathrm{mmol} / \mathrm{l})$ or percentage rise by $50 \%$ or more and decrease in urine output $<0.5 \mathrm{ml} / \mathrm{kg} /$ hour for $>6$ hours) were included. ${ }^{6}$ Patients with Chronic Kidney Disease (CKD) and AKI superimposed on CKD were excluded. Serial monitoring of biochemical parameters was performed.

Nephrology consultation was sought regarding the, need, frequency and timing for initiation of dialysis (electrolyte abnormalities refractory to medical treatment, volume overload with congestive heart failure and pulmonary edema refractory to standard therapy, severe metabolic acidosis, uremia or serum creatinine $>5.65 \mathrm{mg} / \mathrm{dl}$ ). Dialytic support was initiated early in the course of illness.

Further evaluation to aid in diagnosis included renal doppler, Magnetic Resonance Angiography and renal biopsy in case of rapidly progressing renal failure, acute nephritic illness, unexplained AKI. All patients were followed up till 3 months after the acute event/ time of presentation, for recovery of renal functions.

At 3 months postpartum, final renal function assessment regarding further intervention or need for continuing dialysis was carried out.

Outcome parameters were assessed in terms of; complete recovery where serum creatinine returned to its normal levels, partial recovery when creatinine did not return to its normal value, but dialysis was not required and no recovery when creatinine did not return to its normal value and patient required further dialysis.

Data analysis was done using SPSS version 22.0. Categorical data was analysed using Chi square test and quantitative data was analysed using t- test and multiple regression analysis.

\section{RESULTS}

The patient age ranged from 19-45 years. Majority of the patients $(57.5 \%)$ presented in postpartum period. $15 / 37$ $(40.5 \%)$ were preterm and $22 / 37(59.4 \%)$ were at term gestation and $3 / 40(7.5 \%)$ patients presented in postabortal period (Table 1). $14(35 \%)$ patients delivered at our institute and the rest delivered at other hospitals and were later referred to our institute.

Table 1: Demographic profile of the patients.

\begin{tabular}{|ll|}
\hline Parameters & Mean \pm range \\
\hline Age (years) & $25.9 \pm 4.7$ \\
\hline Gestation at presentation (weeks) & $32.6 \pm 4.4$ \\
\hline BMI $\left(\mathrm{Kg} / \mathrm{m}^{2}\right)$ & $24.3 \pm 2.4$ \\
\hline Booked cases & $2(5 \%)$ \\
\hline Unbooked cases & $38(95 \%)$ \\
\hline Parity & \\
\hline Primiparous & $22(55 \%)$ \\
\hline Multiparous & $18(45 \%)$ \\
\hline Presentation time & \\
\hline Antenatal & $14(35 \%)$ \\
\hline Post-natal & $23(57.5 \%)$ \\
\hline Post-abortal & $3(7.5 \%)$ \\
\hline $\begin{array}{l}\text { Urine output on admission: } \\
\text { Oliguria }\end{array}$ & $21(52.5 \%)$ \\
\hline Anuria & $10(25 \%)$ \\
\hline Hemodynamic instability & $7(17.5 \%)$ \\
\hline
\end{tabular}

As regards mode of delivery $8(20 \%)$ had vaginal delivery, 14(35\%) underwent ceserean, 14 (35\%) had preterm vaginal delivery and $1(2.5 \%)$ remained undelivered as she expired due to Hepatitis E Virus (HEV) infection with Multiple Organ Dysfunction (MODS). In the present study sepsis was the commonest (11/40) etiology. Only two patients (5\%) presented with sepsis in third trimester whereas six patients (15\%) developed sepsis in the puerperium and three patients (7.5\%) had postabortal sepsis. As regards postabortal sepsis, two of the patients who underwent surgical abortion outside had retained products of conception and needed dilatation and curettage to remove septic focus after admission in our institute.

Late pregnancy AKI was attributed to abruptio placentae in two patients (5\%). Among those who presented in the puerperium, five patients (12.5\%) had Postpartum Haemorrhage (PPH), three patients $(7.5 \%)$ had HELLP (Haemolysis, Elevated liver enzymes, Low platelets) syndrome and eclampsia was the etiology in five patients (12.5\%). Three patients (7.5\%) had Acute Fatty Liver of Pregnancy (AFLP) as the cause of AKI and out of those two patients, two presented in the third trimester and other presented in the postpartum period. Patients who were diagnosed with Thrombotic Microangiopathy (TMA) presented in puerperium. No significant correlation was found between AKI etiology and maternal outcome ( $\mathrm{p}=>0.05$ ) (Table 2).

Renal biopsy was done in three patients who did not show improvement in renal functions after RRT for prognostication. Histopathology revealed acute tubular necrosis (ATN) and acute cortical necrosis (ACN) each in two patients of puerperal sepsis and TMA in one patient. 
Table 2: Etiology of AKI.

\begin{tabular}{|c|c|c|c|c|c|c|}
\hline $\begin{array}{l}\text { Cause of AKI } \\
\text { (no. of patients) }\end{array}$ & & $\begin{array}{l}\text { Complete } \\
\text { recovery }(\%)\end{array}$ & $\begin{array}{l}\text { Partial } \\
\text { recovery }\end{array}$ & $\begin{array}{l}\text { Death } \\
(\%)\end{array}$ & $\begin{array}{l}\text { No } \\
\text { recovery }\end{array}$ & $\begin{array}{l}\text { P (chi } \\
\text { square) }\end{array}$ \\
\hline \multirow[t]{3}{*}{ Sepsis (11) } & Antenatal & $1(14.3)$ & - & $1(33.3)$ & - & \multirow{3}{*}{0.56} \\
\hline & Postnatal & $3(42.9)$ & $1(100 \%)$ & $2(66.7)$ & - & \\
\hline & Postabortal & $3(42.9)$ & - & - & - & \\
\hline \multirow[t]{2}{*}{ Hemorrhage (7) } & Abruption & $1(25)$ & - & $1(50)$ & & \multirow{2}{*}{0.64} \\
\hline & Postpartum hemorrhage & $3(75)$ & $1(100 \%)$ & $1(50)$ & - & \\
\hline \multirow[t]{2}{*}{ HTN disorders (8) } & Eclampsia & $4(57.1)$ & - & $1(100)$ & - & \multirow{2}{*}{0.62} \\
\hline & HELLP & $3(42.9)$ & - & - & - & \\
\hline \multirow[t]{6}{*}{ Others (14) } & AFLP & - & - & $1(33.3)$ & $1(100 \%)$ & \\
\hline & Acute gastroenteritis & $1(14.3)$ & - & - & - & \\
\hline & Acute pyelonephritis & $3(42.9)$ & - & - & - & \\
\hline & $\begin{array}{l}\text { Thrombotic } \\
\text { microangiopathy }\end{array}$ & - & $2(100 \%)$ & $1(33.3)$ & - & \\
\hline & Tropical illness (malaria) & $1(14.3)$ & - & - & - & \\
\hline & $\mathrm{HEV}+$ & $2(28.6)$ & - & $1(33.3)$ & - & \\
\hline
\end{tabular}

The mean pre-dialysis serum creatinine was $4.3 \pm 3.2$ $\mathrm{mg} / \mathrm{dl}$ (range $1.6-13.8 \mathrm{mg} / \mathrm{dl}$ ) with median of 3 in the study population (Table 3 ).

Table 3: Laboratory parameters on admission.

\begin{tabular}{|ll}
\hline Parameters & Number of cases $(\%)$ \\
\hline Haematological & \\
\hline Anemia $(<11 \mathrm{gm} / \mathrm{dl})$ & $37(92.5)$ \\
\hline Thrombocytopenia $(<1.5 \mathrm{lac})$ & $35(87.5)$ \\
\hline Leucocytosis $(\mathrm{TLC}>14000)$ & $29(72.5)$ \\
\hline Renal function tests & \\
\hline Serum creatinine $(>1 \mathrm{mg} / \mathrm{dl})$ & $40(100)$ \\
\hline Hypokalemia & $7(17.5)$ \\
\hline Hyperkalemia & $14(35)$ \\
\hline Evidence of hemolysis & \\
\hline Schistiocytes on PBF & $8(20)$ \\
\hline Hyperbilirubinemia $(>1.1 \mathrm{mg} / \mathrm{dl})$ & $24(60)$ \\
\hline LDH $(>480 \mathrm{U} / \mathrm{L})$ & $37(92.5)$ \\
\hline Blood gas analysis & $19(47.5)$ \\
\hline Metabolic acidosis & $6(15)$ \\
\hline Coagulogram & \\
\hline Hypofibrinogenemia $(<2 \mathrm{~g} / \mathrm{l})$ & \\
\hline
\end{tabular}

Dialysis was the commonest mode of treatment except in $12 / 40(30 \%)$ patients who were managed conservatively (Table 4).

The indications for dialysis in the study patients included severe metabolic acidosis in 19 (47.5\%), hyperkalemia in $10(25 \%)$, none of the patients had uremic features like encephalopathy, pericarditis. Serum creatinine $>5.65 \mathrm{mg} \%$ was found in $8(20 \%)$. Oliguria/anuria was found in $25(62.5 \%)$. Volume overload was present in only one patient. Dialysis was done in $20(50 \%)$ patients who were refractory to medical therapy. Patients had more than one indication for dialysis.

Table 4: Treatment.

\begin{tabular}{|ll|}
\hline Methods & N $(\%)$ \\
\hline Conservative & $12(30)$ \\
\hline Hemodialysis & $24(60)$ \\
\hline Peritoneal dialysis & $4(10)$ \\
\hline Dialysis f/b Plasmapheresis & $2(5)$ \\
\hline
\end{tabular}

Two patients who received plasmaphresis had TMA and puerperal sepsis as the etiology behind AKI. Four patients received peritoneal dialysis because of hemodynamic instability- one patient underwent 40 sessions. The mean number of hemodialysis sessions required by patients were 6.5 (range 1-40).

If dialysis was given, chances of complete recovery will be there $(\mathrm{OR}=0.77)($ Table 5$)$.

So, it is not AKI per se which leads to mortality but it's the underlying cause and most of the patients who underwent dialysis early in their disease course recovered completely.

The mean difference of duration of anuria was significantly different in complete recovery and others group (Partial/no recovery/death). Mean duration of oliganuria was 6.9 days. With increase in duration of anuria, chances of complete recovery are less $(\mathrm{p}=0.036)$ (Table 6).

Multivariate analysis of present study was done as two groups: A) Complete recovery and B) Others (Partial/no recovery/death). 
Table 5: Renal replacement therapy and maternal outcome.

\begin{tabular}{|llllll} 
& Complete recovery & $\begin{array}{l}\text { Others (partial/ no } \\
\text { recovery/ death) }\end{array}$ & Total & $\begin{array}{l}\text { Adjusted } \\
\text { odds ratio }\end{array}$ & $\begin{array}{l}\text { p value } \\
\text { (unadjusted) }\end{array}$ \\
\hline Dialysis & $17(68 \%)$ & $11(73.3 \%)$ & $28(70 \%)$ & 0.77 & 0.13 \\
\hline No dialysis & $8(32 \%)$ & $4(26.6 \%)$ & $12(30 \%)$ & $(0.18-3.19)$ & \\
\hline Total & $25(100 \%)$ & $15(100 \%)$ & $40(100 \%)$ & & \\
\hline
\end{tabular}

Table 6: Mean difference of serum creatinine and duration of anuria with maternal outcome.

\begin{tabular}{|llll|} 
& Complete recovery & $\begin{array}{l}\text { Others (partial/ no } \\
\text { recovery/ death) }\end{array}$ & $\begin{array}{l}\text { P value (by independent } \\
\text { t- test) }\end{array}$ \\
\hline Pre-dialysis serum creatinine & $4.02 \pm 2.64$ & $4.14 \pm 3.0$ & 0.903 \\
\hline Duration of anuria & $3.92 \pm 3.7$ & $11.8 \pm 13.1$ & 0.036 \\
\hline
\end{tabular}

TABLE 7: Multivariate analysis using standard logistic regression among complete recovery and no/partial recovery/death group and selected independent variables to analyse adjusted odds ratio.

\begin{tabular}{|lllllll|}
\hline $\begin{array}{l}\text { Independent } \\
\text { factors }\end{array}$ & Beta coefficient & S.E. & p value & Adjusted odds ratio & \multicolumn{2}{c|}{ L5\% CI for 0R } \\
\hline Postpartum period & -0.200 & 0.745 & .788 & 0.818 & 0.190 & Upper \\
\hline Duration of anuria & -2.915 & 1.378 & .034 & 0.054 & 0.004 & 0.808 \\
\hline Predialysis S. Cr & 0.423 & 0.669 & .527 & 1.527 & 0.411 & 5.668 \\
\hline
\end{tabular}

Significant correlation has been found between one variable: anuria and complete recovery. Taking normal urine output as a reference, as urine output became nil, odds of complete renal recovery decreases $(\mathrm{OR}=0.054$, 95\%CI 0.004-0.808, $\mathrm{p}=0.034$ ). No correlation has been found between postpartum day and predialysis serum creatinine with maternal complete renal recovery $(\mathrm{p}>=0.05)$ (Table 7).

Perinatal outcome: Out of 37 patients, 21(56.7\%) had live births and 16 patients (43.2\%) had still births. Still births were most commonly observed in $7 / 37$ (18.9\%) patients with sepsis followed by two patients with abruption in which still birth rate was $100 \%$ in the present study.

\section{DISCUSSION}

AKI is defined as an abrupt decline in Glomerular Filtration Rate (GFR) sufficient to decrease the elimination of nitrogenous waste products (urea and creatinine) and other uremic toxins. ${ }^{7}$

There is approximately $40-65 \%$ increase in GFR after conception and which returns to prepregnancy values in the first 3 months postpartum. ${ }^{8-9}$ Renal plasma flow increases up to $85 \%$ in the second trimester. 8 These hemodynamic changes explain a serum creatinine reduction in pregnant women to $0.4-0.5 \mathrm{mg} / \mathrm{dl}$. (Normal $=0.5-1.5 \mathrm{mg} / \mathrm{dl}$ )

In present study almost all patients, 39 (97.5\%) were referred to our institute from other hospitals. The mean age of the study population was $25.9 \pm 4.7$ years similar to the study of Aggarwal et al $(26 \pm 3.8$ years $) .{ }^{10}$ Most of the patients presented in various studies in the postpartum period like in present study, 26 patients (65\%) were referred in the postpartum period (including postabortal patients) and only $14(35 \%)$ came antenatally. ${ }^{11-12} 6$ patients $(15 \%)$ had renal failure due to puerperal sepsis in present study. In the study by Aggarwal et al, 10 Godara et al and Kilari et al, AKI due to puerperal sepsis was reported in 20 (40\%), 36 (63.1\%), 12 (29.2\%) patients respectively. ${ }^{10,11,12}$ Antenatal sepsis developed in two patients $(5 \%)$ in present study but none of above studies reported cases of antenatal sepsis as a cause of AKI. Postabortal sepsis was the cause in 3 patients $(7.5 \%)$ in present study which includes one patient in the first trimester and two in second trimester. Septic abortion accounted for majority of the cases in the study conducted in Kashmir valley by Najar et al and they reported $15(75 \%)$ cases in first trimester and 5(25\%) cases in second trimester. ${ }^{13}$

Antepartum and postpartum haemorrhage have been reported as major causes of AKI in pregnancy. ${ }^{14-18}$ In the present study abruptio placentae was found in two patients $(5 \%)$ and five patients $(12.5 \%)$ had $\mathrm{PPH}$ which led to AKI.

In severe pre-eclampsia/eclampsia, renal failure is most probably due to ATN. ${ }^{19}$ In the present study, 5 (12.5\%) had eclampsia and $3(7.5 \%)$ had HELLP.

TMA was the cause in three patients $(7.5 \%)$ in present study. Silva GB et al 20 reported Thrombotic Thrombocytopenic Purpura (TTP) in 5.5\% and Hemolytic Uremic Syndrome (HUS) in $9.1 \%$ cases. No other study reported cases of TMA as cause of AKI. 
Aggarwal et al reported AKI in the first trimester due to prerenal cause- hyperemesis gravidarum in one patient. In index study only one patient had acute gastroenteritis in the postpartum period. ${ }^{10}$ Malaria was the etiology only in one patient in the present study whereas Godara et al reported three $(5.2 \%)$ such cases. ${ }^{11}$ Three patients $(7.5 \%)$ developed Disseminated Intravascular Coagulopathy (DIC) in present study as was also reported by Godara et al in $8.7 \%$ of the patients. ${ }^{11}$

Other etiologies behind AKI in present study were AFLP, acute pyelonephritis and Hepatitis E virus (HEV) positive in three patients $(7.5 \%)$ each.

In present study 21 patients $(52.5 \%)$ were oliguric, 10 patients $(25 \%)$ were anuric and nine patients $(22.5 \%)$ were non-oliguric. Godara et al reported oliguria and anuria in $64.9 \%$ and $21 \%$ respectively. Patients with sepsis, TMA, PPH and AFLP have prolong oliganuria of more than 10 days duration. ${ }^{11}$

In present study, the interval between onset of renal failure and referral to our institute varied from one to 15 days. Whereas in the study by Godara et al interval between onset and referral was one to 30 days. $^{11}$ Morbidity of AKI in developing countries could be higher than developed countries due to late identification and referral of the patients. As regards need for additional investigations, CECT KUB was done in six patients and it revealed ACN in three of them secondary to TMA in two and AFLP in one patient.

One patient was diagnosed to have emphysematous pyelonephritis on CT. ACN because of puerperal sepsis led to complete maternal recovery. The other two patients who had AFLP and TMA as a cause of AKI recovered partially. One patient with TMA who expired during the course of treatment also had ACN. Godara et al reported ACN in 13 patients and ATN in 40 patients and stated it to be associated with septicemia in 28 patients. ${ }^{11}$

Dialysis was the commonest mode of therapy of AKI in our institute. 24 patients $(60 \%)$ received hemodialysis and four patients $(10 \%)$ received peritoneal dialysis due to hemodynamic instability. Oliguria/ anuria was the most common indication for dialysis in 25 patients $(62.5 \%)$ followed by being refractory to medical therapy in 20 patients $(50 \%)$. Whereas in study by Pahwa et al 25 $(92 \%)$ patients required hemodialysis; of these, $17(68 \%)$ patients required more than five sessions of hemodialysis. Five patients $(20 \%)$ had irreversible kidney injury and three $(60 \%)$ of them were transplanted. ${ }^{21}$

Renal failure was previously thought to be irreversible but complete and partial recovery does occur in about $30 \%$ of these cases. ${ }^{22}$

Complete recovery was seen in 25 patients $(62.5 \%)$ in which sepsis was the most common etiology of AKI in index study compared to Godara et al where it was
$52.64 \%(n=30) .{ }^{11}$ Partial recovery was the outcome in $4(10 \%)$ in the present study and causes were sepsis, PPH and TMA in two patients (mean creatinine of $3.65 \mathrm{mg} / \mathrm{dl}$ ) which is same as reported by Kilari et al and anuria was present in three patients with partial recovery in present study. AFLP was the cause behind no recovery in one patient in index study. ${ }^{12}$

Maternal mortality occurred in $10(25 \%)$ patients in present study population and the causes were AFLP and puerperal sepsis in two each and antenatal sepsis, $\mathrm{PPH}$, eclampsia with intracranial bleed, TMA, abruption with DIC and HEV with organ failure in one each which is comparable to study by Godara et al in nine patients $(15.79 \%)$ and the causes were septicemia in four patients $(4.44 \%)$, preeclampsia in three patients $(3.33 \%)$,

APH in one and PPH in one patient. TMA and AFLP accounted for bad maternal outcomes in present study. ${ }^{11}$ But etiology of AKI was not associated to unfavorable evolution $(\mathrm{p}$ value $=>0.05)$. None of studies have commented upon correlation of AKI etiology with maternal outcome.

Godara et al while analysing AKI related to various independent variables, identified significant correlation of maternal recovery with duration of anuria $(p=0.001)$ and significant correlation was also found in present study $(\mathrm{p}=0.034) .^{11}$

Dialysis initiated earlier in the disease course had better outcomes in the form of complete recovery of renal function. In present study, fetal loss was seen in 16 cases $(43.2 \%)$. Still births were more common in maternal sepsis $(75 \%)$ and abruptio placentae (100\%).

\section{CONCLUSION}

An obstetrician should have a broad knowledge about physiological alterations in the renal system in pregnancy to apply the best evidence-based strategies in treating patients with AKI considering both maternal and fetal effects of the pathology and its management.

Early diagnosis and prompt referral to tertiary care centre can avoid potentially life-threatening AKI and its sequel. Prolonged oliguria/anuria is an important poor prognostic marker for unfavourable outcome and in such cases dialysis if initiated early can improve fetal and maternal outcome.

\section{ACKNOWLEDGMENTS}

Authors would like to express their gratitude towards all the participants in the study.

\section{Funding: No funding sources \\ Conflict of interest: None declared}

Ethical approval: The study was approved by the Institutional Ethics Committee 


\section{REFERENCES}

1. Goplani KR, Shah PR, Gera DN, Gumber M, Dabhi M, Feroz A et al. Pregnancy related acute renal failure: a single centre experience. Indian J Nephrol. 2008;18(1):17-21.

2. Kumar S, Ramakrishna C, Sivakumar V. Pregnancy related acute renal failure. J Obstet Gynecol India. 2006;56:308-10.

3. Chugh KS, Singhal PC, Sharma BK, Pal Y, Mathew MT, Dhall K, et al. Acute renal failure of obstetric origin. Obstet Gynecol 1976;48(6):642-46.

4. Prakash J, Singh RG, Tripathi K et al. Acute renal failure in pregnancy. J Obstet Gynaecol India 1985;35:233-38.

5. Chugh KS, Sakhuja V, Malhotra HS, Pereira BJ.. Changing trends in acute renal failure in third world countries-Chandigarh study. Q J Med 1989;73(3):1117-23.

6. Mehta RL, Kellum JA, Shah SV, Molitoris BA, Ronco C, Warnock DG et al. Acute Kidney Injury Network. Crit Care 2007;11(2):R31.

7. Jefferson A, Thurman JM, Schrier RW. Pathophysiology and Etiology of Acute Kidney Injury. In: Jurgen F, Johnson RJ, Feehally J. Comprehensive clinical nephrology. 4th ed. New York: Elsevier; 2010.

8. Conrad KP, Lindheimer M. Renal and cardiovascular alterations. In: Lindheimer M, Roberts J, Cunningham F, eds. Chesley's hypertensive disorders in pregnancy. 3rd ed. Amsterdam: Elsevier; 2009:297-334.

9. Jeyabalan A, Conrad KP. Renal function during normal pregnancy and preeclampsia. Front Biosci 2007;12(1):2425-37.

10. Rohina SA, Vineet VM, Anil FJ, Manoj G. Acute renal failure in pregnancy: Our experience. Saudi J Kidney Dis Transpl 2014;25(2):450-55.

11. Suraj MG, Vivek BK, Hargovind LT, Aruna VV, Pankaj RS, Manoj RG et al. Clinical profile and outcome of Acute kidney injury related to pregnancy in developing countries: A single centre study fromIndia. Saudi J Kidney Dis Transpl 2014; 25(4):906-11.

12. Kilari SK, Chinta RK, Vishnubhotla SK. Pregnancy related acute renal failure. J Obstet Gynecol India 2006; 56(4):308-10.
13. Najar MS, Shah AR, Wani IA, Reshi AR, Banday KA, Bhat MA et al. Pregnancy related acute kidney injury: A single centre experience from the Kashmir Valley. Indian Journal of Nephrology 2008;18(4):159-61.

14. Smith K, Browne JC, Shackman R, Wrong OM. Acute Renal Failure of Obstetric Origin: An Analysis of 70 Patients. Lancet 1965;2(7408):351-54.

15. Kennedy AC, Burton JA, Luke RG, Briggs JD, Lindsay RM, Allison ME et al. Factors affecting the prognosis in acute renal failure: A survey of 251 cases. Q J Med 1973;42(165):73-86.

16. Ali A, Zaffar S, Mehmood A, Nisar A. Obstetrical acute renal failure from Frontier Province : A 3 years prospective study. J Postgrad Med Inst 2004;18(1):109-17.

17. Rassmussen PE, Nielson FR. Hydronephrosis during pregnancy: A literature survey. Eur J Obstet Gynecol Reprod Biol 1988;27(3):249.

18. Conrad KP, Gandley RE, Ogawa T. Endothelin mediates renal vasodilitation and hyperfiltration during pregnancy in chronically instrumented conscious rats. Am J Physiol 1999;276(5):767.

19. Sibai BM, Ramadan MK. Acute renal failure in pregnancy complicated by hemolysis, elevated liver enzymes, and low platelets. Am J Obstet Gynecol 1993;168(6):1682-90.

20. Silva GB, Monteiro FA, Mota RM, Paiva JG, Correia JW, Bezerra Filho JG et al. Acute kidney injury requiring dialysis in obstetric patients. Arch Gynecol Obstet 2009; 279(2):131-7.

21. Pahwa N, Bharani R, Kumar R. Post-Partum Acute Kidney Injury. Saudi J Kidney Dis Transpl 2014;25(6):1244-47

22. Beaufils M. Pregnancy. In: Davison A, Cameron J, Grunfeld, Ponticelli C, Ritz E, Winearls C, Ypersele C. Oxford text book of clinical nephrology.3rd ed. Great Clarendon Street: Oxford university press; 2005:1604-12.

Cite this article as: Kaur A, Chopra S, Suri V, Kohli HS. Spectrum of acute kidney injury in obstetrics. Int J Reprod Contracept Obstet Gynecol 2018;7:401621. 